\title{
Erythema nodosum
}

\section{prof. MUDr. Zdeněk Doležel, CSc., MUDr. Erik Nedorost, MUDr. Tereza Pinkasová \\ Pediatrická klinika LF MU a FN Brno}

\section{Klíčová slova: erythema nodosum, panikulitis}

EN je nejčastější formou panikulitidy (PAN) v dětském věku a klinická manifestace většinou nevyvolává diagnostické rozpaky. Při PAN dochází vlivem faktorů zánětlivých, ale i nezánětlivých k degenerativním změnám podkožního

Obr. 1. Morfy EN na ventrální ploše levého bérce se zbytky lokální masti

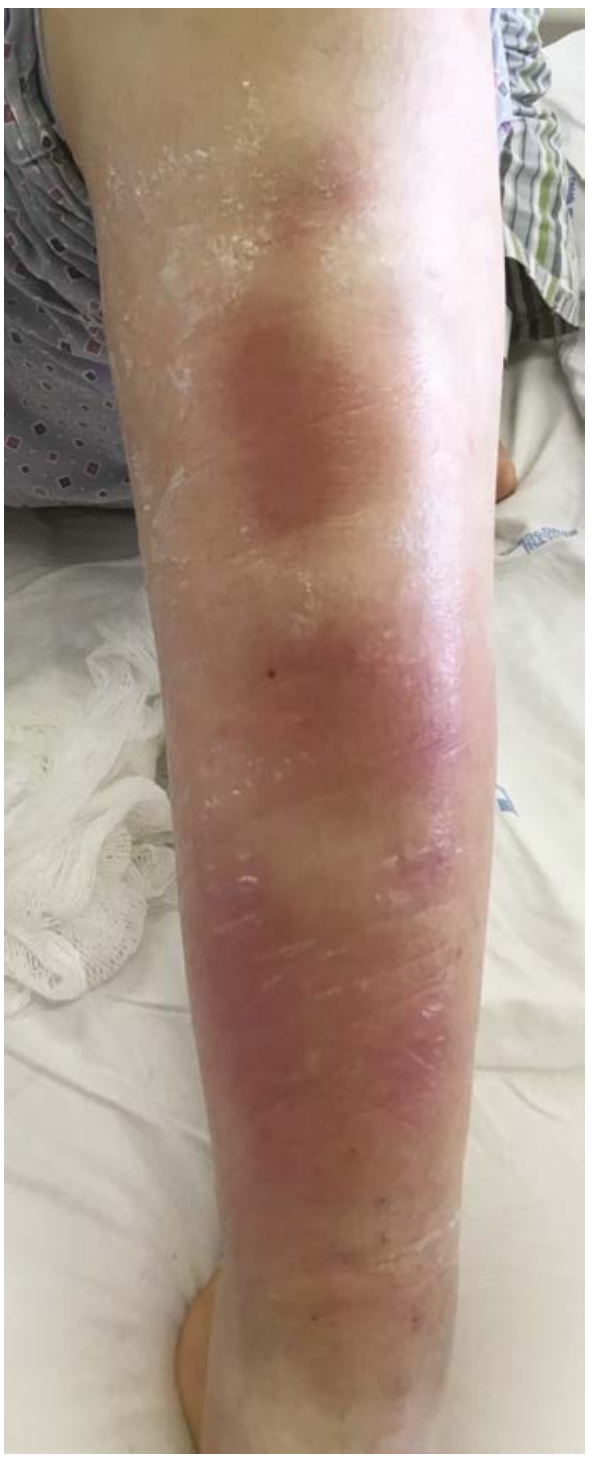

tuku a vaziva. Patogeneticky je EN vysvětlováno jako opožděná hypersenzitivní imunitní reakce IV. typu provázená tvorbou imunokomplexů, které jsou deponovány v okolí sept podkožního tuku a vaziva. Bez ohledu na vyvolávající príčinu

\section{Obr. 2. EN na dorzálnístraně levého predloktí}

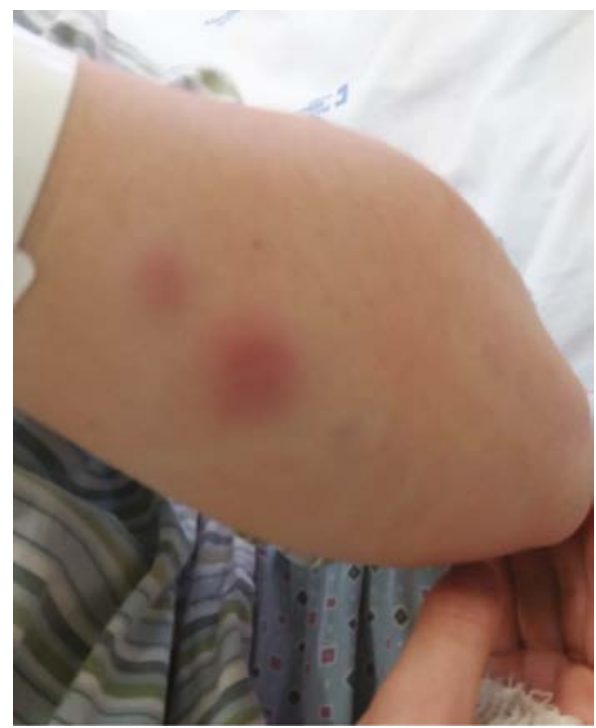

jsou projevy EN častější u žen a to zejména mezi 20.-30. rokem života. V dětském věku je EN relativně vzácné a podle nečetných literárních zdrojů je ve srovnání s populací dospělých zastoupení obou pohlaví téměř stejné, přitom spiše převažuj jedinci adolescentního věku. Častými prodromy EN jsou především horečka/subfebrilie, artritida/ artralgie, únava/slabost. Subkutánní noduly při EN jsou tuhé, na pohmat teplé a bolestivé, mají obvykle červenofialovou barvu, jejich velikost je většinou v rozmezí $2-8 \mathrm{~cm}$. Typicky se EN manifestuje symetrickým postižením zejména pretibiální partie dolních končetin, ale morfy mohou být také nad extensory stehen/paži/předloktí, je však možné také postižení trupu a ojediněle i obličeje (obr. 1, 2). EN obvykle spontánně regreduje během 2-8 týdnů, nikdy nedochází k jeho ulceraci nebo jizevnatým změnám, naproti tomu ale může recidivovat. Nekonstantním následkem kožních změn bývá hyperpigmentace. Často se u nemocných s EN i pres opakovaná pomocná vyšetření nepodaří etiologii objasnit a EN je

Tab. 1. Některé príčiny erythema nodosum

\begin{tabular}{|c|c|c|}
\hline \multicolumn{3}{|c|}{ Infekce } \\
\hline Virové & Bakteriální & Mykotické \\
\hline \multirow{3}{*}{$\begin{array}{l}\text { EB-virus } \\
\text { Cytomegalovirus } \\
\text { Parvovirus B19 } \\
\text { Hepatitis B, C }\end{array}$} & \multirow{3}{*}{$\begin{array}{l}\text { Streptococcus spp. } \\
\text { Mycoplasma pneumoniae } \\
\text { Chlamydia pneumoniae } \\
\text { Campylobacter jejuni } \\
\text { Meningococcus spp. } \\
\text { Yersinióza } \\
\text { Tularémie } \\
\text { Leptospiróza } \\
\text { TBC } \\
\text { Bartonelóza }\end{array}$} & $\begin{array}{l}\text { Histoplasmóza } \\
\text { Kokcidiomykóza } \\
\text { Aspergilóza }\end{array}$ \\
\hline & & Parazitární \\
\hline & & $\begin{array}{l}\text { Toxoplasmóza } \\
\text { Amebiáza } \\
\text { Giardiáza }\end{array}$ \\
\hline Léky & Systémové choroby & Enteropatie \\
\hline \multirow{3}{*}{$\begin{array}{l}\text { Penicilin } \\
\text { Sulfonamidy } \\
\text { Salicyláty } \\
\text { Kortikoidy } \\
\text { Kontraceptiva } \\
\text { Phenytoin }\end{array}$} & \multirow{3}{*}{$\begin{array}{l}\text { Sarkoidóza } \\
\text { Sweetův syndrom } \\
\text { Behçetova nemoc } \\
\text { Sjögrenův syndrom }\end{array}$} & $\begin{array}{l}\text { Nespecifické střevní záněty } \\
\text { Syndrom krátkého střeva }\end{array}$ \\
\hline & & Jiné \\
\hline & & $\begin{array}{l}\text { Těhotenství } \\
\text { Idiopatické }\end{array}$ \\
\hline
\end{tabular}

KORESPONDENČNÍ ADRESA AUTORA: prof. MUDr. Zdeněk Doležel, CSc., dolezel.zdenek@fnbrno.cz Pediatrická klinika LF MU a FN Brno

Černopolní 9, 61300 Brno
Cit. zkr: Pediatr. praxi. 2019; 20(3): 165-166 Článek prìjat redakcí: 8. 4. 2019

Článek príijat k publikaci: 12. 4. 2019 
hodnoceno jako idiopatické, podle většiny literárních sdělení je tomu u 30-50 \% nemocných. Na druhé straně bývá uváděna asociace s řadou vyvolávajících činitelů (Tab. 1). Nejčastěji bývají v této souvislosti uváděny streptokokové infekce, ale část z recentních literárních zdrojů dokládá, že v důsledku některých faktorů (např. včasná léčba onemocnění vyvolaných streptokoky, jejich pozměněné antigenní vlastnosti, zlepšení socio- ekonomických podmínek) začíná převažovat jiná etiologie EN. Pokud se u nemocných s EN daří prokázat jako vyvolávající prríčinu některou infekci, je v naprosté většině detekováno pouze jediné agens; anekdotálně je uváděna manifestace EN prì infekci kombinované.

I když EN nepatří k častým kožním projevưm v dětském věku, je jeho diagnostika poměrně snadná a je především klinická. V rámci diferenciálně diagnostické rozvahy mưže být v některých prípadech podobný nález u panikulitidy lupusové nebo vyvolané chladem, dále při nodulární vaskulitidě, deficitu a-1-antitrypsinu nebo necrobiosis lipoidica diabeticorum. $\checkmark$ ojedinělých prípadech se tak pro stanovení konečné diagnózy nevyhneme kožní biopsii.

Podpořeno: MZ ČR-RVO (FN Brno 65269705) 